Original Article

\title{
ANTIMICROBIAL AND ENZYME ACTIVITY PRODUCED BY BACILLUS SPP. ISOLATED FROM SOIL
}

\author{
PANNAPA POWTHONG ${ }^{*}$, PATTRA SUNTORNTHITICHAROEN ${ }^{2}$
}

1Faculty of Medical Technology, Rangsit University, Pathumthanee, Thailand 12000, ${ }^{2}$ Department of Medical Sciences, Faculty of Science, Rangsit University, Pathumthanee, Thailand 12000

Email: pannapa_pt@yahoo.com

Received: 05 Jul 2016 Revised and Accepted: 30 Jan 2017

\section{ABSTRACT}

Objective: Our study was to isolate Bacillus spp. from soil all around 6 geographic parts of Thailand and screen for potential antimicrobial.

Methods: A total of 43 isolates which isolated from 100 samples of soil were investigated. Preliminary screening was based on antimicrobial activity against 16 strains of pathogenic bacteria and fungi, including 10 strains of Methicillin-resistant Staphylococcus aureus (MRSA), and 1 strain of Methicillin-sensitivity Staphylococcus aureus (MSSA), Extended spectrum beta lactamases (ESBL) Escherichia coli, Samonella Typhymurium, Klebsiella pneumoniae, Candida albicans, Cryptococcus neoformans respectively by cross streak, agar diffusion and modified microdilution technique. Moreover, the selected Bacillus spp. were then screened for bioactive enzyme, including chitinese, chitosanese, amylase, cellulose, caseinase, gelatinase, esterase and lipase production of different selective media for 24 and $48 \mathrm{~h}$ by direct spot agar.

Results: There are 2 isolates, namely 23 and 49 showed particularly strong activity inhibitions against MRSA and pathogenic C. albicans. The diameter of hydrolysis zone results from screened for bioactive enzyme revealed that there were 36 isolate showed particularly strong activities with a broad spectrum enzyme. The isolate which produced the widest diameter hydrolysis zone in gelatin, cellulose and starch are 294,303 , and 290 respectively.

Conclusion: Our result indicated Bacillus spp. from soil in Thailand showed potent antibacterial activity and bioactive compounds production.

Keywords: Antimicrobial activity, Bioactive enzyme, Soil, Drug resistant bacteria, Bacillus spp

(C) 2016 The Authors. Published by Innovare Academic Sciences Pvt Ltd. This is an open access article under the CC BY license (http://creativecommons.org/licenses/by/4.0/) DOI: http://dx.doi.org/10.22159/ijpps.2017v9i3.13895

\section{INTRODUCTION}

The uses of antibiotics are widespread in clinical medicine, agriculture, aquaculture, and veterinary promote the development of antibiotic resistances in infectious microbial strains and eventually reflects a very serious problem in the treatment of pathogenic microbes. Serious bacterial and fungal infections are increasingly recognized as important causes of morbidity and mortality, especially among debilitated patients [1-3]. Therefore, it is necessary to search for novel antibiotics through natural, synthetic or semisynthetic sources. Microorganisms are the most potential source for production of natural therapeutic agents. Thus, searches of bioactive compound from microorganisms are considered for developing the therapeutic drugs, which are highly effective, low toxic and having minor environmental impact. In the course of screening for new antibiotics, several research studies are currently oriented towards isolation of new microorganism species from different soils and ecosystems $[4,5]$.

One of the important abilities of the microorganisms is enzyme production ability. Since microbial enzyme was high production capability, low cost and susceptibility to genetic manipulation. Actually, the enzymes of microbial origin have a high biotechnological interest such as in the processing of foods, manufacturing of detergents, textiles, pharmaceutical products, environmental improvement, medical therapy and in molecular biology $[6,8]$. Therefore, it's necessary to find microorganisms which represent a new source of microbial enzyme to obtain more enzymes with different potentialities and also produce enzymes for specific substrate, with different requirements in temperature range, $\mathrm{pH}$ and presence of different ions, for different production processes [7].

Within microorganisms, Bacillus species are one of the most abundant bacterial strains found in soil, with the characteristic of endospore-forming, Gram positive bacteria. Many investigations have been carried out to isolate different strains of terrestrial bacillus and identify their wide range of antimicrobial activities and other bioactive enzyme. This genus is widely used in industrial processes for enzyme production $[9,10]$ in large-scale industrial fermentations $[11,12]$ and as plant growth-promoting microorganisms [13-15]. Their metabolites show antagonistic properties, so they are used against different pathogens [16-19]. These bacteria are also employed as constituents of probiotic supplements for animals and humans [20].

Thailand is an explored ecosystem which located in the tropical rainforest area and is greatly diversity of living organism. Therefore, it may be a source of new microorganisms producing new compounds.

In the present work, we described a preliminary characterization of Bacillus species isolated from soil of Thailand and to assess their antimicrobial activity as well as enzyme production capacity based on molecular methods.

\section{MATERIALS AND METHODS}

\section{Chemical and reagents}

Bacterial culture agar and broth were purchased from BBL Co., Ltd. and Becton, Dickinson and Co., Ltd. (USA). All chemicals were purchased from Sigma-Aldrich Co., Inc. (St. Louis, MO, USA) and Ajex Co., Ltd. (Australia).

\section{Isolation of Bacillus strain}

One hundred soil samples were collected from various parts of the agricultural area in Thailand. According to geographical variations, 6 parts of Thailand were collected. There were 35 samples from the southern part, 27 samples from the northeast part, 18 samples from the central part, 8 samples from the eastern part, 7 samples from the northern part and 5 samples from the western part. Microorganisms from the samples were isolated by the dilution plate method. Briefly, 
soil samples were serially 10 -fold dilution. Then $100 \mu \mathrm{l}$ culture broths from serially diluted of $10^{-3}-10^{-5}$ were pipetted and spreaded on basal mineral salt agar (BSA) by the spread plate method and incubated at room temperature for 24-48 h. Single colonies were selected from a plate which produced 30-300 colonies per plate and streaked on BSA and identified. In the identification tests of strains, spore morphology, gram characteristics and motility were examined. In addition, the following identification tests were carried out: utilization of citrate, Voges-Proskauer (VP) test, gelatin liquefaction, esculin and starch hydrolysis, acid production from D-glucose, Larabinose, D-xylose, D-mannitol, lactose, salicin, sucrose and maltose. The production of gas from glucose, the production of catalase, nitrate reduction, and the production of $\mathrm{H}_{2} \mathrm{~S}$ and acid from Triple Sugar Iron (TSI) medium were also tested. According to the results obtained, the isolates were shown belong to the genus Bacillus [21, 22]. The pure culture was maintained in BSA stored at $4{ }^{\circ} \mathrm{C}$ and activated in the same media for $24 \mathrm{~h}$ before experimental use.

\section{Test microbial pathogen}

Test bacteria pathogen used in this experiment was kindly received from the department of medical sciences, faculty of science, Rangsit University. There was composed of 14 strains of pathogenic bacteria: Escherichia coli, ESBL, Klebsiella pneumoniae, Salmonella Typhimurium, Methicillin sensitive Staphylococcus aureus (MSSA) (ATCC25923) and 10 strains of Methicillin resistant Staphylococcus aureus (MRSA); MRSA 4, MRSA 5, MRSA 6, MRSA 14, MRSA 18, MRSA 28, MRSA 29, MRSA 31, MRSA 34, MRSA 36. Test fungi pathogens were composed of 2 strains of pathogenic fungi: Candida albicans and Cryptococcus neoformans.

\section{Preliminary-antimicrobial assay}

Determinations of antimicrobial activities of pure Bacillus spp. cultures were performed by the modified cross-streak method (MCSM). The petri dishes containing Muller-Hinton agar were prepared and inoculated with Bacillus spp. cultures by a single streak in the center of the petri dish and incubated at room temperature for $2 \mathrm{~d}$. This was done to provide enough time for the active organism to produce the antibiotic substance, which will diffuse into the agar medium. The cross-streak method [23] was modified by keeping the distance between the test pathogen streak fixed, i.e. $1 \mathrm{~cm}$; length of the test pathogen streak line, $3 \mathrm{~cm}$; streak width, $0.5 \mathrm{~cm}$; length of Bacillus spp. streak, $7 \mathrm{~cm}$ and width of the Bacillus spp. streak, $0.5 \mathrm{~cm}$. The markings were drawn on a transparency sheet, which acted as a template and was attached below the plates to facilitate streaking and thereafter in quantifying the results.

The plates were seeded with test organisms by streaking perpendicular to the line of Bacillus spp. growth. The plates containing active organisms were kept for $7 \mathrm{~d}$ to determine whether the test pathogens made any further growth towards the master streak, or whether they remain stationary, or whether lysis of the test pathogens occurred [23]. Antagonism was observed based on the inhibitory interaction between the Bacillus spp. and test strains were measured in millimeter by using a scale. The experiment was carried out in triplicates.

\section{Semi-quantitative-antimicrobial assay}

Antimicrobial activity was tested by agar well diffusion method. Isolated colonies of test bacteria or yeast pathogens was suspended in a sterile $0.85 \% \mathrm{NaCl}$ solution and measured the turbidity by using spectrophotometry $(\mathrm{OD}=0.08-0.1$ at $625 \mathrm{~nm}$ for bacteria and $\mathrm{OD}=$ $0.12-0.15$ at $530 \mathrm{~nm}$ for yeast). One hundred $\mu \mathrm{l}$ of test organism was spread over the surface of the Muller-Hinton agar using sterile cotton swab. Six mm diameter wells in agar were made using a sterile cork borer. Isolated colony of antibiotic producing Bacillus spp. was suspended in a sterile nutrient broth solution and measured the turbidity by using spectrophotometry $(\mathrm{OD}=0.08-0.1$ at $625 \mathrm{~nm}$ ). Twenty $\mu \mathrm{l}$ of antibiotic producing bacteria suspension was added to each well. Similarly, $20 \mu \mathrm{l}$ of nutrient broth were used as negative controls. The plates were incubated at $35 \pm 2{ }^{\circ} \mathrm{C}$ for $24 \mathrm{~h}$ for test bacteria pathogen and Candida albicans and $48 \mathrm{~h}$ for
Cryptococcus neoformans. The diameter of inhibition zone around the well was measured by using a scale.

\section{Preparation of extracellular filtration}

Isolated colony of each antibiotic producing Bacillus spp. was suspended in a sterile $0.85 \% \mathrm{NaCl}$ solution and measured the turbidity by using spectrophotometry (OD $=0.08-0.1$ at $625 \mathrm{~nm}$ ). Then, $5 \%(\mathrm{v} / \mathrm{v})$ of this standardized inoculum was inoculated into 15 $\mathrm{ml}$ centrifuge tube containing $5 \mathrm{ml}$ of nutrient broth and incubated at room temperature on static condition for $2 \mathrm{~d}$. Next, the culture medium was centrifuged at $5000 \mathrm{~g}$ at $4{ }^{\circ} \mathrm{C}$ for $10 \mathrm{~min}$. The supernatant was collected and filtered by $0.45 \mu \mathrm{m}$ used as an extracellular filtration for quantitative screening of antibiotic producing Bacillus spp.

\section{Determination of the quantitative-antimicrobial assay}

The minimum inhibitory concentration (MIC) and minimum bactericidal concentration (MBC) of the extracellular filtration were determined by using the standard broth microdilution method and a modified resazurin microtiter plate assay as recommended by the NCCLS and CLSI methodology. The NCCLS, the CLSI M27 A2, the CLSI M38-A were intended for bacterial testing with a few modifications [24-26]. The serial two fold dilutions were made in a concentration ranged from undiluted to 1:512. Fifty of Test sample solutions and $50 \mu \mathrm{L}$ of bacteria or fungi suspension containing $1 \times 10^{6} \mathrm{CFU} / \mathrm{ml}$ was added into each well of the 96-well microplate. Gentamicin (initial concentration $1,000 \mu \mathrm{g} / \mathrm{ml}$ ) was used as positive control for bacteria. Ketoconazole (initial concentration $1,000 \mu \mathrm{g} / \mathrm{ml}$ ) was used as a positive control for fungi. Each well of the negative control contained $50 \mu \mathrm{l}$ of microbial suspension and $50 \mu \mathrm{L}$ of Muller-Hinton broth. Microtiter plates were incubated at $37^{\circ} \mathrm{C}, 24 \mathrm{~h}$. After incubation period $10 \mu \mathrm{l}$ of the $0.18 \%$ sterile resazurin indicator solution was added to each well. The color change was then assessed visually. The blue or purple color (oxidized form) was recorded as positive. Any color changes from blue or purple to pink or colorless (reduced form) were recorded as negative. The lowest concentration at which the blue or purple color occurred was taken as the MIC value. All tests were carried out in triplicate.

The MBC was determined by inoculating 1 loop of sample from wells that showed no apparent growth from the MIC assays onto Muller Hinton agar (MHA) plates. The plates were incubated at $37^{\circ} \mathrm{C}, 24 \mathrm{~h}$. After the incubation period, the plates were examined for growth or lack of growth for each dilution subculturing. No growth indicated that the extracellular filtration sample was bactericidal at that dilution. Growth indicated that the sample was bacteriostatic at that dilution. The lowest concentration showing no visible growth on agar subculture was taken as MBC value.

\section{Determination of the biological enzyme activities of Bacillus strains}

The productions of following enzymatic activities were analyzed: amilolytic activity (starch hydrolysis), esterase activity, lipolytic activity, proteolytic activity (protease, gelatinase), cellulolytic activity, chitinase, and chitosanase by the spot agar method. The enzymatic activities were investigated after inoculated colony within 2 to $14 \mathrm{~d}$ incubation on the specific culture media, according to specific methodologies for each investigated enzyme. All assays were done in triplicate.

\section{Determination of amilolytic activity}

The methodology used was described by Hankin and Anagnostakis [27]. The microorganisms were heavy inoculated in basal mineral salts medium (BMSM) with $0.01 \%$ of soluble starch, pH 6.0. After incubation at 24 and $48 \mathrm{~h}$, the cultures were treated under Lugol's iodine solution, which allowed the visualization of clear halos around the colonies.

\section{Determination of the esterase and lipolytic activity}

The media used was containing basal mineral salts medium (BMSM), $0.1 \mathrm{~g} / \mathrm{l} \mathrm{CaCl}$, and $0.1 \mathrm{~g} / \mathrm{l}$ Phenol red. To the sterilized culture media, previously sterilized Tween 80 was added at a final concentration of 
$1 \%(\mathrm{v} / \mathrm{v})$. This medium was inoculated with the isolates and the presence of clear halos around the colonies was observed.

Determination of the lipolytic activity, Tween 80 was substituted by Tween 20. The presence of clear halos around the colonies was observed.

\section{Determination of the proteolytic activity}

To determine the casein hydrolysis, basal mineral salts medium (BMSM) containing of skimmed milk (10 g/l) autoclaving. The microorganisms were inoculated and after the growth period, $2.0 \mathrm{ml}$ of hydrochloric acid ( $\mathrm{HCl}) 0.1 \mathrm{~mol} / 1$ was added to the plates and the presence of clear halos around the colonies was observed. In another method, the hydrolysis of gelatin were determined using the BMSM, containing bacteriological gelatin (4.0 g l/1). After incubation at $30{ }^{\circ} \mathrm{C}$ for $24-48 \mathrm{~h}$., the plates were covered with Frazier's revealers (distilled water $100 \mathrm{ml}, \mathrm{HCl} 20.0 \mathrm{ml}$ and mercury dichloride $15.0 \mathrm{~g}$ ) [28]. The presence of a clear halo around the bacterial growth was observed.

\section{Determination of the cellulolytic activity}

Basal mineral salts medium with $10 \mathrm{~g} / \mathrm{l}$ carboxymethyl cellulose was used to determine the cellulose hydrolysis, the microorganisms were heavy inoculated. After incubation at $30{ }^{\circ} \mathrm{C}$ for $24-48 \mathrm{~h}$, the plates were covered with $0.2 \%$ congo red and destained with $1 \mathrm{M}$ $\mathrm{NaCl}$ for $15 \mathrm{~min}$ [29]. The presence of clear halos around the colonies was observed.

\section{Determination of the chitinase and chitosanase activity}

The media were basal mineral salts medium (BMSM) agar containing of colloidal chitin $(10 \mathrm{~g} / 1)$ autoclaving. This medium was inoculated with the isolates and the presence of halos observed after incubation at $30^{\circ} \mathrm{C}$ for 2 to $14 \mathrm{~d}$.

Determination of the chitosanase activity, colloidal chitin was substituted by colloidal chitosan $(10 \mathrm{~g} / 1)$. The presence of clear halos around the colonies was observed after incubation at $30^{\circ} \mathrm{C}$ for 2 to $14 \mathrm{~d}$.

\section{Statistical analysis}

All experimental results were carried out in triplicate and were expressed as average of three analyses $\pm \mathrm{SD}$ (Standard Deviation) using the SPSS version 22.

\section{RESULTS AND DISCUSSION}

The need for new antimicrobial agents, in general, comes from the increasing rates of resistance to existing antibiotics. The present study was pointing out to Bacillus spp. due to their wide ubiquity in nature and genetic and metabolic diversity leading the production of several antibiotics and enzymes, these bacteria have become increasingly interesting for different biotechnological applications nowadays.

In this study $12(27.91 \%)$ Bacillus spp. isolates from 43 isolates which selected from 100 various soil samples have inhibited at least 7 test microbial pathogen; MRSA, MSSA, Candida albicans, and Cryptococcus neoformans in modified cross-streak method, and well diffusion method. The modified cross-streak method and well diffusion method gave a number of inhibition than the quantitative inhibition by broth microdilution that uses extracellular filtration is summarized in table 1, 2 and 3. As it can be seen in modified crossstreak method, isolate 39 and 418 were the most efficient isolate. Isolate 39 inhibited 14 bacterial and isolate 418 inhibited 13 bacterial and 1 fungal strains respectively. Isolate 23 was also inhibited 12 bacterial and 1 fungal (table 1). However, in well diffusion result, isolate 39 inhibited 4 bacterial strains, isolate 23 inhibited 1 fungal strain (Candida albicans), and isolate 23 also showed the same inhibition activity to 1 fungal strain (Cryptococcus neoformans) respectively (table 2).

Our result was correlated with Kaur et al. who isolated antibiotics producing microorganisms from soil in Punjab, India. These microorganisms were investigating based on the disc diffusion method, agar well method, streak agar method and found that there were 2 isolates suitable in inhibition the growth of Staphylococcus aureus and Proteus vulgris indicator strains [30].

Table 1: Antimicrobial activity of the Bacillus strains against test microbial pathogen at $48 \mathrm{~h}$ by modified cross-streak method.

\begin{tabular}{|c|c|c|c|c|c|c|c|c|c|c|c|c|c|c|c|c|c|c|}
\hline \multirow{2}{*}{$\begin{array}{l}\mathbf{N} \\
\mathbf{o} \\
.\end{array}$} & \multirow{2}{*}{$\begin{array}{l}\text { ID } \\
\text { Num } \\
\text { ber }\end{array}$} & \multicolumn{17}{|c|}{ Inhibition zone of antimicrobial activity at $48 \mathrm{~h}($ mean $\pm S D, \mathrm{~mm})$} \\
\hline & & $\begin{array}{l}\text { MRS } \\
\text { A4 }\end{array}$ & $\begin{array}{l}\text { MRS } \\
\text { A5 }\end{array}$ & $\begin{array}{l}\text { MRS } \\
\text { A6 }\end{array}$ & $\begin{array}{l}\text { MRS } \\
\text { A14 }\end{array}$ & $\begin{array}{l}\text { MRS } \\
\text { A18 }\end{array}$ & $\begin{array}{l}\text { MRS } \\
\text { A28 }\end{array}$ & $\begin{array}{l}\text { MRS } \\
\text { A29 }\end{array}$ & $\begin{array}{l}\text { MRS } \\
\text { A31 }\end{array}$ & $\begin{array}{l}\text { MRS } \\
\text { A34 }\end{array}$ & $\begin{array}{l}\text { MRS } \\
\text { A36 }\end{array}$ & $\begin{array}{l}\text { E. coli } \\
\text { (ESBL) }\end{array}$ & $\begin{array}{l}\text { S. } \\
\text { Typhim } \\
\text { urium }\end{array}$ & $\begin{array}{l}\text { K. } \\
\text { pneum } \\
\text { oniae }\end{array}$ & $\begin{array}{l}\text { MSSA } \\
\text { (ATCC } \\
\text { 25923) } \\
\end{array}$ & $\begin{array}{l}\text { C. } \\
\text { albic } \\
\text { ans } \\
\end{array}$ & $\begin{array}{l}C . \\
\text { neofor } \\
\text { mans } \\
\end{array}$ & $\begin{array}{l}\text { Total } \\
\text { inhib } \\
\text { ition }\end{array}$ \\
\hline 1 & 18 & - & - & $\begin{array}{l}24.0 \\
\pm 2.4\end{array}$ & $\begin{array}{l}25.0 \\
\pm 1.4\end{array}$ & - & $\begin{array}{l}13.0 \\
\pm 2.4\end{array}$ & $\begin{array}{l}11.0 \\
\pm 2.4\end{array}$ & $\begin{array}{l}7.0 \pm \\
2.4\end{array}$ & - & $\begin{array}{l}6.0 \pm \\
2.4\end{array}$ & - & - & $7.0 \pm 2.7$ & $\begin{array}{l}27.0 \pm 2 . \\
2\end{array}$ & $\begin{array}{l}15.0 \\
\pm 3.6\end{array}$ & - & 9 \\
\hline 2 & 23 & $\begin{array}{l}15.0 \\
\pm 2.5\end{array}$ & - & $\begin{array}{l}16.0 \\
\pm 2.2\end{array}$ & $\begin{array}{l}17.0 \\
\pm 1.4\end{array}$ & $\begin{array}{l}10.0 \\
\pm 2.4\end{array}$ & $\begin{array}{l}10.0 \\
\pm 2.7\end{array}$ & $\begin{array}{l}10.0 \\
\pm 2.4\end{array}$ & $\begin{array}{l}3.0 \pm \\
1.4\end{array}$ & - & $\begin{array}{l}15.0 \\
\pm 3.2\end{array}$ & $\begin{array}{l}8.0 \pm 2 . \\
24\end{array}$ & $\begin{array}{l}21.0 \pm 3 \\
2\end{array}$ & $\begin{array}{l}11.0 \pm 2 . \\
5\end{array}$ & $\begin{array}{l}23.0 \pm 1 \\
4\end{array}$ & $\begin{array}{l}22.0 \\
\pm 1.4\end{array}$ & - & 13 \\
\hline 3 & 24 & $\begin{array}{l}10.0 \\
\pm 2.3\end{array}$ & - & - & - & $\begin{array}{l}8.0 \pm \\
2.2\end{array}$ & $\begin{array}{l}3.0 \pm \\
1.4\end{array}$ & - & - & - & $\begin{array}{l}11.0 \\
\pm 2.2\end{array}$ & - & $7.0 \pm 2.2$ & $8.0 \pm 2.1$ & $\begin{array}{l}22.0 \pm 1 \\
1\end{array}$ & $\begin{array}{l}20.0 \\
\pm 2.7\end{array}$ & - & 8 \\
\hline 4 & 39 & $\begin{array}{l}2.00 \\
\pm 2.7\end{array}$ & $\begin{array}{l}18.0 \\
\pm 2.4\end{array}$ & $\begin{array}{l}22.0 \\
\pm 1.4\end{array}$ & $\begin{array}{l}25.0 \\
\pm 1.1\end{array}$ & $\begin{array}{l}13.0 \\
\pm 3.2\end{array}$ & $\begin{array}{l}20.0 \\
\pm 2.6\end{array}$ & $\begin{array}{l}20.0 \\
\pm 2.2\end{array}$ & $\begin{array}{l}10.0 \\
\pm 2.4\end{array}$ & $\begin{array}{l}15.0 \\
\pm 3.2\end{array}$ & $\begin{array}{l}23.0 \\
\pm 1.4\end{array}$ & $\begin{array}{l}7.0 \pm 2 . \\
24\end{array}$ & $\begin{array}{l}15.0 \pm 3 \\
2\end{array}$ & $\begin{array}{l}12.0 \pm 2 . \\
2\end{array}$ & $\begin{array}{l}27.0 \pm 2 . \\
1\end{array}$ & - & - & 14 \\
\hline 5 & 75 & $\begin{array}{l}10.0 \\
\pm 2.2\end{array}$ & $\begin{array}{l}5.0 \pm \\
2.5\end{array}$ & $\begin{array}{l}5.0 \pm \\
2.5\end{array}$ & $\begin{array}{l}9.0 \pm \\
2.4\end{array}$ & $\begin{array}{l}10.0 \\
\pm 2.2\end{array}$ & $\begin{array}{l}9.0 \pm \\
2.5\end{array}$ & $\begin{array}{l}10.0 \\
\pm 2.2\end{array}$ & $\begin{array}{l}10.0 \\
\pm 2.4\end{array}$ & - & - & - & - & - & $\begin{array}{l}15.0 \pm 3 \\
1\end{array}$ & - & - & 9 \\
\hline 6 & 386 & - & - & $\begin{array}{l}8.0 \pm \\
2.1\end{array}$ & - & $\begin{array}{l}9.0 \pm \\
2.4\end{array}$ & - & $\begin{array}{l}11.0 \\
\pm 2.2\end{array}$ & - & - & $\begin{array}{l}8.0 \pm \\
2.4\end{array}$ & - & - & - & $\begin{array}{l}13.0 \pm 2 . \\
2\end{array}$ & $\begin{array}{l}11.0 \\
\pm 2.6\end{array}$ & - & 6 \\
\hline 7 & 405 & - & - & $\begin{array}{l}7.0 \pm \\
2.6\end{array}$ & $\begin{array}{l}6.0 \pm \\
2.2\end{array}$ & $\begin{array}{l}9.0 \pm \\
2.6\end{array}$ & - & $\begin{array}{l}8.0 \pm \\
2.2\end{array}$ & $\begin{array}{l}10.0 \\
\pm 2.4\end{array}$ & - & $\begin{array}{l}10.0 \\
\pm 2.2\end{array}$ & $\begin{array}{l}2.0 \pm 1 . \\
0\end{array}$ & $7.0 \pm 2.4$ & $\begin{array}{l}5.0 \pm 2.2 \\
4\end{array}$ & $9.0 \pm 2.4$ & $\begin{array}{l}4.0 \pm \\
2.1\end{array}$ & $5.0 \pm 2.4$ & 12 \\
\hline 8 & 418 & - & $\begin{array}{l}18.0 \\
\pm 2.4\end{array}$ & $\begin{array}{l}15.0 \\
\pm 3.2\end{array}$ & $\begin{array}{l}10.0 \\
\pm 2.4\end{array}$ & $\begin{array}{l}20.0 \\
\pm 2.2\end{array}$ & $\begin{array}{l}15.0 \\
\pm 3.4\end{array}$ & $\begin{array}{l}20.0 \\
\pm 2.4\end{array}$ & $\begin{array}{l}20.0 \\
\pm 2.2\end{array}$ & $\begin{array}{l}15.0 \\
\pm 3.2\end{array}$ & $\begin{array}{l}14.0 \\
\pm 2.4\end{array}$ & $\begin{array}{l}3.0 \pm 2 . \\
24\end{array}$ & $\begin{array}{l}10.0 \pm 2 \\
4\end{array}$ & $\begin{array}{l}14.0 \pm 2 \\
24\end{array}$ & $\begin{array}{l}13.0 \pm 3 \\
6\end{array}$ & - & $3.0 \pm 2.8$ & 14 \\
\hline 9 & 421 & - & - & $\begin{array}{l}11.0 \\
\pm 2.4\end{array}$ & $\begin{array}{l}1.05 \\
\pm 3.1\end{array}$ & $\begin{array}{l}12.0 \\
\pm 2.4\end{array}$ & $\begin{array}{l}12.0 \\
\pm 2.3\end{array}$ & $\begin{array}{l}11.0 \\
\pm 2.4\end{array}$ & $\begin{array}{l}10.0 \\
\pm 2.2\end{array}$ & - & - & - & $6.0 \pm 2.1$ & $\begin{array}{l}10.0 \pm 2 \\
24\end{array}$ & - & - & - & 8 \\
\hline
\end{tabular}

Inhibition zone from modified cross-streak method in the table is derived from 3 experiments and given in mean \pm SD ( $\mathrm{n}=3$ ).

Table 2: Antimicrobial activity of Bacillus strains against test microbial pathogen at $24 \mathrm{~h}$ and $48 \mathrm{~h}$ by agar well diffusion.

\begin{tabular}{|c|c|c|c|c|c|c|c|c|c|c|c|c|c|}
\hline \multirow[t]{3}{*}{ No. } & \multirow[t]{3}{*}{ Isolate } & \multicolumn{12}{|c|}{ Inhibition zone of agar diffusion at $24 \mathrm{~h}$ and $48 \mathrm{~h}($ mean $\pm \mathrm{SD}, \mathrm{mm})$} \\
\hline & & \multicolumn{2}{|c|}{ MRSA28 } & \multicolumn{2}{|c|}{ MRSA29 } & \multicolumn{2}{|c|}{ MRSA31 } & \multicolumn{2}{|c|}{ MRSA34 } & \multicolumn{2}{|c|}{ C. albicans } & \multicolumn{2}{|c|}{ C. neoformans } \\
\hline & & $24 \mathrm{~h}$ & $48 \mathrm{~h}$ & $24 \mathrm{~h}$ & $48 \mathrm{~h}$ & $24 \mathrm{~h}$ & $48 \mathrm{~h}$ & $24 h$ & $48 \mathrm{~h}$ & $24 h$ & $48 \mathrm{~h}$ & $24 h$ & $48 \mathrm{~h}$ \\
\hline 1 & 23 & - & - & - & - & - & - & - & - & $20.6 \pm 0.7$ & $21.0 \pm 3.2$ & - & - \\
\hline 2 & 39 & $7.0 \pm 2.2$ & $8.0 \pm 2.4$ & $6.5 \pm 1.2$ & $6.5 \pm 1.1$ & $6.5 \pm 1.1$ & $7.0 \pm 2.1$ & $8.0 \pm 2.5$ & $8.5 \pm 0.50$ & - & - & - & - \\
\hline 3 & 405 & - & - & - & - & - & - & - & - & - & - & $11.0 \pm 2.7$ & $11.5 \pm 1.1$ \\
\hline 4 & 418 & - & - & - & - & - & - & - & - & - & - & $7.5 \pm 0.71$ & $8.0 \pm 2.2$ \\
\hline
\end{tabular}


Inhibition zone by agar well diffusion in the table is derived from 3 experiments and given in mean $\pm S D(n=3)$. It is essential to determine the MIC values of the substances to evaluate the antimicrobial efficacy. MIC and minimum bactericidal concentration (MBC) values of the extracellular filtration for Isolates 39 has shown inhibition against MRSA 28 (dilution 1:32) and 34 (dilution 1:4) while isolates 23 has shown inhibition against Candida albicans (dilution 1:4) by used broth microdilution evaluation (table 3).

Inhibition of this bacterium indicates that Bacillus isolates 23 and 39 might lead to a path for the production of novel antibiotic against MRSA and Candida albicans. Likewise, in our investigation, narrowspectrum activity against gram positive bacteria like MRSA and fungi like Candida albicans was found in compounds produced by Bacillus isolates 39 and 23 respectively.
It leads to the conclusion that even the bioactive compounds from extracellular filtration are diffuse throughout the medium. There may be a small amount of these compounds which not enough to inhibit the growth of microbial pathogen when diluted and compared to commercial drug. It may relate to external factors such as incubation period, amount of Bacillus cell biomass, temperature, and amount of microbial pathogen biomass. There is need to test the bioactive compound extraction when using the suitable solvent extracting in this case.

However, there are also evidences that these compounds are consistently produced by these isolates even after several generations grown in a lab using standard media. Among the tested organisms MRSA is most susceptible for the compounds produced by all 12 Bacillus isolates.

Table 3: Minimum inhibitory concentration (MIC) and minimum bactericidal concentration (MBC) of extracellular filtration from different isolates of Bacillus strains against test microbial pathogen determined by broth microdilution

\begin{tabular}{|c|c|c|c|c|c|c|c|c|c|c|c|c|c|}
\hline \multirow[t]{3}{*}{ No. } & \multirow[t]{3}{*}{ Isolate } & \multicolumn{12}{|c|}{ Tested microorganisms } \\
\hline & & \multicolumn{2}{|l|}{ MRSA28 } & \multicolumn{2}{|l|}{ MRSA29 } & \multicolumn{2}{|l|}{ MRSA31 } & \multicolumn{2}{|l|}{ MRSA34 } & \multicolumn{2}{|c|}{ C. albicans } & \multicolumn{2}{|c|}{ C. neoformans } \\
\hline & & $\begin{array}{l}\text { MIC } \\
\text { dilution }\end{array}$ & $\begin{array}{l}\text { MBC } \\
\text { dilution }\end{array}$ & $\begin{array}{l}\text { MIC } \\
\text { dilution }\end{array}$ & $\begin{array}{l}\text { MBC } \\
\text { dilution }\end{array}$ & $\begin{array}{l}\text { MIC } \\
\text { dilution }\end{array}$ & $\begin{array}{l}\text { MBC } \\
\text { dilution }\end{array}$ & $\begin{array}{l}\text { MIC } \\
\text { dilution }\end{array}$ & $\begin{array}{l}\text { MBC } \\
\text { dilution }\end{array}$ & $\begin{array}{l}\text { MIC } \\
\text { dilution }\end{array}$ & $\begin{array}{l}\text { MFC } \\
\text { dilution }\end{array}$ & $\begin{array}{l}\text { MIC } \\
\text { dilution }\end{array}$ & $\begin{array}{l}\text { MFC } \\
\text { dilution }\end{array}$ \\
\hline 1 & 23 & - & - & - & - & - & - & - & - & $1: 4$ & G & - & - \\
\hline 2 & 39 & $1: 32$ & G & G & ND & G & ND & $1: 4$ & G & - & - & - & - \\
\hline 3 & 405 & - & - & - & - & - & - & - & - & - & - & G & ND \\
\hline 4 & 418 & - & - & - & - & - & - & - & - & - & - & G & ND \\
\hline control & $\begin{array}{l}\text { Gentamicin } \\
(\mu \mathrm{g} / \mathrm{ml})\end{array}$ & 62.50 & 62.50 & 1.95 & 1.95 & 1.95 & 1.95 & 1.95 & 1.95 & ND & ND & ND & ND \\
\hline control & $\begin{array}{l}\text { Ketoconazole } \\
(\mu \mathrm{g} / \mathrm{ml})\end{array}$ & ND & ND & ND & ND & ND & ND & ND & ND & 0.98 & 0.98 & 0.98 & 0.98 \\
\hline
\end{tabular}

* $\mathrm{G}=$ Growth; ND = Not Done. These data in the table is derived from 3 experiments and given in mean $\pm S D(n=3)$.

Table 4: Biological enzyme activities of Bacillus strains

\begin{tabular}{|c|c|c|c|c|c|c|c|c|c|}
\hline \multirow[t]{2}{*}{ No. } & \multirow[t]{2}{*}{ ID Number } & \multicolumn{8}{|c|}{ Clear zone of interested biological enzyme at 2-14 d (mm.) } \\
\hline & & Chitin & Chitosan & Starch & Cellulose & Skim milk & Gelatin & Tween 20 & Tween 80 \\
\hline 1 & 196 & - & $8 \pm 2.24$ & $11 \pm 2.24$ & $5 \pm 1.41$ & $17 \pm 1.41$ & $17 \pm 1.41$ & - & - \\
\hline 2 & 290 & - & $10 \pm 2.24$ & $26 \pm 2.24$ & $14 \pm 2.24$ & $35 \pm 1.41$ & $40 \pm 2.24$ & - & $8 \pm 2.24$ \\
\hline 3 & 294 & - & $8 \pm 2.24$ & $12 \pm 2.24$ & $14 \pm 2.24$ & $45 \pm 1.00$ & $56 \pm 1.41$ & - & - \\
\hline 4 & 299 & - & $5 \pm 1.41$ & $24 \pm 2.24$ & $9 \pm 2.24$ & - & $48 \pm 2.24$ & $6 \pm 2.24$ & $9 \pm 2.24$ \\
\hline 5 & 303 & - & - & $19 \pm 3.16$ & $22 \pm 1.41$ & - & $46 \pm 2.24$ & $8 \pm 2.24$ & $15 \pm 3.16$ \\
\hline 6 & 309 & - & $6 \pm 2.24$ & $23 \pm 1.41$ & $14 \pm 2.24$ & $40 \pm 2.24$ & $38 \pm 2.24$ & $5 \pm 1.41$ & $5 \pm 1.41$ \\
\hline 7 & 315 & - & - & $21 \pm 3.16$ & $6 \pm 2.24$ & - & $30 \pm 2.24$ & $7 \pm 1.41$ & $9 \pm 2.24$ \\
\hline 8 & 318 & - & - & - & $10 \pm 2.24$ & $68 \pm 2.24$ & $35 \pm 1.41$ & - & $10 \pm 2.24$ \\
\hline 9 & 325 & - & $11 \pm 2.24$ & $25 \pm 1.41$ & $18 \pm 2.24$ & $43 \pm 1.00$ & & & \\
\hline 10 & 326 & - & - & $20 \pm 2.24$ & $11 \pm 2.24$ & - & $39 \pm 3.16$ & $7 \pm 1.41$ & $6 \pm 2.24$ \\
\hline 11 & 329 & - & $10 \pm 2.24$ & $18 \pm 2.24$ & $17 \pm 1.41$ & - & $42 \pm 2.24$ & $5 \pm 1.41$ & $7 \pm 1.41$ \\
\hline 12 & 336 & - & $9.0 \pm 2.5$ & $11.0 \pm 3.1$ & - & - & $43.0 \pm 1.4$ & - & $14.0 \pm 1.2$ \\
\hline 13 & 337 & - & - & $14.0 \pm 2.5$ & - & - & $24.0 \pm 2.5$ & - & $15.0 \pm 3.1$ \\
\hline 14 & 340 & - & $8.0 \pm 2.2$ & $12.0 \pm 1.4$ & $11.0 \pm 2.24$ & - & $24.0 \pm 2.1$ & - & - \\
\hline 15 & 341 & - & - & - & - & - & - & - & $10.0 \pm 2.2$ \\
\hline 16 & 346 & - & - & $8.0 \pm 1.2$ & - & - & - & - & - \\
\hline 17 & 354 & - & - & $12.0 \pm 2.4$ & - & - & $11.0 \pm 2.2$ & - & - \\
\hline 18 & 368 & - & - & - & - & $15.0 \pm 3.2$ & $70.0 \pm 3.2$ & - & - \\
\hline 19 & 372 & - & - & - & - & $20.0 \pm 2.2$ & - & $36.0 \pm 1.4$ & - \\
\hline 20 & 373 & - & - & - & - & $25.0 \pm 1.4$ & $40.0 \pm 2.1$ & $18.0 \pm 2.2$ & - \\
\hline 21 & 376 & - & - & - & $10.0 \pm 2.24$ & - & - & - & - \\
\hline 22 & 383 & - & - & - & $10.0 \pm 2.24$ & - & - & - & - \\
\hline 23 & 384 & - & - & - & $3.0 \pm 1.41$ & $17.0 \pm 1.4$ & $40.0 \pm 2.2$ & - & - \\
\hline 24 & 388 & - & - & $6.0 \pm 1.2$ & $10.0 \pm 2.24$ & - & $37.0 \pm 1.4$ & - & - \\
\hline 25 & 394 & - & - & $16.0 \pm 1.7$ & - & $33.0 \pm 3.6$ & $27.0 \pm 1.4$ & - & - \\
\hline 26 & 395 & - & - & $12.0 \pm 2.6$ & $8.0 \pm 2.24$ & $45.0 \pm 1.0$ & $25.0 \pm 1.4$ & - & - \\
\hline 27 & 401 & - & - & $20.0 \pm 1.4$ & $19.0 \pm 2.24$ & - & - & - & - \\
\hline 28 & 404 & - & - & $8.0 \pm 3.4$ & $7.0 \pm 2.24$ & - & $34.0 \pm 2.2$ & - & - \\
\hline 29 & 405 & - & - & $9.0 \pm 2.2$ & $10.0 \pm 2.24$ & - & $33.0 \pm 3.6$ & - & - \\
\hline 30 & 410 & - & - & - & $6.0 \pm 2.24$ & $13 \pm 3.3$ & $26.0 \pm 2.4$ & - & - \\
\hline 31 & 411 & - & - & $12.0 \pm 1.2$ & $7.0 \pm 2.24$ & - & $27.0 \pm 1.4$ & - & - \\
\hline 32 & 412 & - & - & - & - & - & $29.0 \pm 1.1$ & $43.0 \pm 3.1$ & $18.0 \pm 2.4$ \\
\hline 33 & 418 & - & - & $12.0 \pm 3.4$ & $18.0 \pm 2.24$ & $26 \pm 1.4$ & - & - & - \\
\hline 34 & 421 & - & - & - & - & $25 \pm 1.4$ & - & - & - \\
\hline \multirow{2}{*}{35} & 423 & - & - & $18.0 \pm 2.1$ & - & - & - & - & - \\
\hline & Total effectively isolate (\%) & - & $2(4.65)$ & $14(32.56)$ & $12(27.90)$ & $9(20.93)$ & $15(34.88)$ & $3(6.98)$ & $4(9.30)$ \\
\hline
\end{tabular}

Clear zone of interested biological enzyme in the table is derived from 3 experiments and given in mean $\pm \mathrm{SD}(\mathrm{n}=3)$. 
This result was in agreement with the result of Moshafi et al. reported the isolation and characterization of an antibiotic producing Bacillus genus from environmental soil inhibit six bacterial (Escherichia coli, Klebsiella pneumonia, Salmonella typhi, Staphylococcus aureus, Staphylococcus epidermidis, Pseudomonas aeruginosa) and 3 fungal (Candida albicans, Aspergillus flavus, Aspergillus niger) indicator strains [31]. Merghni et al. revealed that 12 Bacillus spp. isolated from 7 Tunisians hypersalines environments have an inhibitory effect against pathogenic Vibrio strains and S. typhymurium ATCC 17802 [32].

The multifarious antimicrobial compounds produced by various Bacillus strains have the ability to address the multidrug resistant problems have been elucidated. However, only a small portion of the antimicrobial molecules potentially produced by this genus has been identified. Bacillus isolates are rather well known for the production of a vast array of structurally unrelated antimicrobial compounds, which include lipopeptides like iturin, surfactin, fengycins, bacteriocins, and bacteriocin like inhibitory substances (BLIS) [33]. While much of the interest in Bacillus bioactive compound is for medicinal use, compounds that may have industrial or agricultural applications are also gaining attention. In particular, chitinese, chitosanese, amylase, cellulose, caseinase, gelatinase, esterase and lipase production are an important enzyme that is used in numerous applications in a variety of industries and there is growing interest in these enzymes with a wider spectrum of biological properties that can function at diverse $\mathrm{pH}$ and temperature ranges. Most of enzymes selected in this study have been widely used in various processes including the industrial, agricultural, biological, pharmacological and environmental fields [34].

In this study 35 Bacillus isolated from 43 isolates were able to degrade the selected enzymes. By 2 isolates (4.65\%), 14 isolates (32.56\%), 12 isolates (27.90\%), 9 isolates $(20.93 \%), 15$ isolates $(34.88 \%), 3$ isolates $(6.98 \%)$, and 4 isolates $(9.30 \%)$ can produce chitosanese, amylase, cellulose, caseinase, gelatinase, esterase and lipase enzyme respectively (table 4). The extracellular enzyme activity of the isolates revealed that the majority of the tested strains is able to produce gelatinase, amylase, and cellulose respectively. The isolate which produced the widest diameter hydrolysis zone in gelatin, cellulose and starch are 294, 303, and 290 respectively.

The present study indicates that some of these might produce good amounts (high activity) of biological enzyme. Some of the isolates have shown significant areas of clear zone, whereas some of them showed less area indicating different rate of enzyme production by different isolates.

Our results similar to Bal et al. who found that all isolated marine Bacillus spp. possess extracellular enzymes amylase and protease [35]. Previous studies reported that the Bacillus bacteria secrete many exoenzymes, such as proteases, carbohydrolases and lipases, which are very efficient in breaking down a large variety of proteins, carbohydrates and lipids into smaller units [36].

\section{CONCLUSION}

We reported here a soil bacterial isolate, identified as Bacillus spp., capable of inhibiting growth of MRSA, MSSA and fungal strains. Four isolates were able to produce quite a good amount of antimicrobial compounds tested in preliminary test and quantitative test. We also determined the biological enzyme activities of interesting isolate which present a good clear zone to chitosan, starch, cellulose, skim milk, gelatin, Tween 20 , and Tween 80 . The present study leads to the need of further in depth studies on these isolated bioactive Bacillus spp. isolates. Further growing those in large scale, modifying culture conditions like changing $\mathrm{pH}$, changing growth media and supplying some stimulants might help in getting better production of the particular bioactive compound and enzyme. Future studies will be done to identify the active isolates up to the species level. The type of antimicrobial agents produced by these isolates will be investigated as well.

\section{ACKNOWLEDGEMENT}

The authors of this research work would like to thank Research Institute, Rangsit University under grant number 69/2555 for overall support; mainly the financial support to P. Powthong.

\section{CONFLICT OF INTERESTS}

Declared none

\section{REFERENCES}

1. Kapil A. The challenge of antibiotic resistance: need to contemplate. Indian J Med Res 2005;121:83-91.

2. Gullo A. Invasive fungal infections: the challenge continues. Drugs 2009;69:65-73.

3. Peleg AY, Hooper DC. Hospital-acquired infections due to gramnegative bacteria. New England J Med 2010:362:1804-13.

4. Mellouli L, Mehdi RB, Sioud S, Salem M, Bejar S. Isolation, purification and partial characterization of antibacterial activities produced by a newly isolated Streptomyces sp. US24 strain. Res Microbiol 2003;154:345-52.

5. Errakhi R, Bouteau F, Lebrihi A, Barakate M. Evidences of biological control capacities of Streptomyces spp. against Sclerotium rolfsii responsible for damping-off disease in sugar beet (Beta vulgaris L.). World J Microbiol Biotechnol 2007;23:1503-9.

6. Pilnik W, Rombouts FM. Polysaccharides and food processing. Carbohydr Res 1985;142:93-105.

7. Falch EA. Industrial enzymes-developments in production and application. Biotechnol Adv 1991;9:643-58.

8. Suganya RS. Screening optimization and production of biosurfactants from Bacillus and Pseudomonas species. Int J Curr Pharm Res 2013;5:19-23.

9. Manachini PL, Parini C, Fortina MG, Benazzi LB. A restriction endonuclease from Bacillus licheniformis. FEBS Lett 1987;214:305-7.

10. Manachini PL, Fortina MG, Parini C. Enzymic modification of vegetable protein by a crude preparation from a strain of Bacillus licheniformis. J Sci Food Agric 1988;45:263-6.

11. Fiechter A. Biosurfactants: moving towards industrial application. Trends Biotechnol 1992;10:208-17.

12. Zukowski MM. Production of commercially valuable products. In: Doi RH, McGoughlin M. editors. Biology of bacilli, applications to industry. Boston: Butterworth-Heinemann; 1992. p. 311-37.

13. Bai Y, D'Aoust F, Smith DL, Driscoll BT. Isolation of plantgrowth-promoting Bacillus strains from soybean root nodules. Can J Microbiol 2002;48:230-8.

14. Joo GJ, Kim YM, Lee IJ, Song KS, Rhee IK. Growth promotion of red pepper plug seedlings and the production of gibberellins by Bacillus cereus, Bacillus macrolides and Bacillus pumilus. Biotechnol Lett 2004;26:487-91.

15. Yilma M, Soran H, Beytli Y. Antimicrobial activities of some Bacillus spp. strains isolated from the soil. Microbiol Res 2006;161:127-31.

16. Czaczyk K, Stachowiak B, Trojanowska K, Gulewicz K. Antifungal activity of Bacillus sp. isolated from compost. Folia Microbiol (Praha) 2000;45:552-4.

17. Mannanov RN. The use of natural bio-agents for the control of cotton phytopathogens. Meded Rijksuniv Gent Fak Landbouwkd Toegep Biol Wet 2001;66:183-6.

18. Al-Ajlani MM, Sheikh MA, Ahmad Z, Hasnain S. Bacillus subtilis strains produce a broad spectrum of bioactive peptides with great potential for biotechnological and biopharmaceutical applications. Microb Cell Fact 2007;6:17.

19. Ongena M, Jacques P. Bacillus lipopeptides: versatile weapons for plant disease biocontrol. Trends Microbiol 2008;16:115-25.

20. Cutting SM. Bacillus probiotics. Food Microbiol 2011;28:214-20.

21. Sneath PA, Mair NS, Sharphe ME. Bergey's Manual Systematic Bacteriology. Vol. 2. William and Wilkins; 1986.

22. Koneman EW, Allen SD, Jandan WM, Schreckenberger PC. 4th Ed. Diagnostic Microbiology; 1992.

23. Fernando C. Screening tests for antibiotics. Mycologia 1947;39:128-30.

24. National Committee for Clinical Laboratory Standards (NCCLS). In 12th informational supplement M-100-S12. Wayne, Pa: NCCLS; 2002.

25. National Committee for Clinical Laboratory Standards. In Approved standard. NCCLS document M38-A. Wayne, Pa: NCCLS; 2002. 
26. National Committee for Clinical Laboratory Standards. Second edition. In: Approved standard M27-A2. Wayne, Pa: NCCLS; 2002.

27. Moshafi1 HM, Forootanfar H, Ameri A. Antimicrobial activity of Bacillus sp. strain fas1 isolated from soil Pak. J Pharm Sci 2011;24:269-75.

28. Smibert RM, Krieg NR. Phenotypic characterization in methods for general and molecular bacteriology. Am Soc Microbiol; 1994. p. 611-51.

29. Hendricks CW, Doyle JD, Hugley B. A new solid medium for enumerating cellulose-utilizing bacteria in soil. Appl Environ Microbiol 1995;61:2016-9.

30. Kaur S, Kaur J, Pankaj PP. Isolation and characterization of antibiotic producing microorganisms from soil samples of certain area of punjab region of India. Int J Pharm Clin Res 2014;6:312-5.

31. Hankin L, Anagnostakis SL. The use of solid media for the detection of enzyme production by fungi. Mycologia 1975;67:597-607.
32. Merghni A, Leban N, Behi A, Bakhrouf A. Evaluation of the probiotic properties of Bacillus spp. strains isolated from Tunisian hypersaline environments. Afr J Microbiol Res 2014;8:398-405.

33. Stein T. Bacillus subtilis antibiotics: structures, syntheses and specific functions. Mol Microbiol 2005;56:845-57.

34. Chuan LD. Review of fungal chitinases. Mycopathologia 2006;161:345-60.

35. Bal S, Mishra RR, Rath B, Sahu HK, Thatoi HN. Characterization and extracellular enzyme activity of predominant marine Bacillus spp. isolated from sea water of Orissa Coast. India Malays J Microbiol 2009;2:87-93.

36. Ninawe AS, Selvin J. Probiotics in shrimp aquaculture: avenues and challenges. Crit Rev Microbiol 2009;35:43-66.

\section{How to cite this article}

- $\quad$ Pannapa Powthong, Pattra Suntornthiticharoen. Antimicrobial and enzyme activity produced by Bacillus spp. isolated from soil. Int J Pharm Pharm Sci 2017;9(3):205-210. 